OPEN ACCESS

Edited by:

Jan A. Plock,

University of Zurich, Switzerland

Reviewed by:

Radu Olariu,

University Hospital Bern, Switzerland

David J. Hunter-Smith,

Monash University Plastic and

Reconstructive Surgery Group,

Australia

${ }^{*}$ Correspondence:

Thomas H. Jovic

thjovic@doctors.org.uk

Specialty section:

This article was submitted to

Reconstructive and Plastic Surgery,

a section of the journal

Frontiers in Surgery

Received: 10 August 2017

Accepted: 07 November 2017

Published: 29 November 2017

Citation:

Jovic TH, Jessop ZM, Slade $R$, Dobbs T and Whitaker IS (2017) The Use of Keystone Flaps in Periarticular

Wound Closure: A Case Series.

Front. Surg. 4:68.

doi: 10.3389/fsurg.2017.00068

\section{The Use of Keystone Flaps in Periarticular Wound Closure: A Case Series}

\author{
Thomas H. Jovic ${ }^{1,2 *}$, Zita M. Jessop ${ }^{1,2}$, Robert Slade', Thomas Dobbs ${ }^{1,2}$ \\ and lain S. Whitaker ${ }^{1,2}$
} ${ }^{1}$ Welsh Centre for Burns and Plastic Surgery, Morriston Hospital, Swansea, United Kingdom, ${ }^{2}$ Reconstructive Surgery and
Regenerative Medicine Research Group, Institute of Life Sciences, Swansea, United Kingdom

The Keystone perforator island flap (Keystone flap), is a Type A fasciocutaneous advancement flap, consisting of two $\mathrm{V}$ to $\mathrm{Y}$ advancement flaps. Skin cancer excision around joints presents a number of reconstructive challenges. Owing to the mobile nature of joints, the optimal periarticular reconstructive option should possess the ability to provide adequate tissue coverage and withstand regional changes in tensile pressures. We report a single-surgeon series of five cases of periarticular keystone flap between 2014 and 2017. Data were collected from operation notes, clinical photography, histopathology, and outpatient clinic records. The indication for keystone flap was skin cancer in all cases $(n=5)$. The largest defect size post-excision in was $75 \mathrm{~mm} \times 40 \mathrm{~mm} \times 15 \mathrm{~mm}$. All keystone flaps demonstrate a color and cosmetic appearance comparable to adjacent tissue. There were no major postoperative complications including flap failure or impaired range of joint movement in the follow up period. Superficial wound infection occurred postoperatively in one case. This is the first case series to discuss the use of keystone flaps in periarticular wound closure. Locoregional fasciocutaneous wound coverage offered by keystone flaps may alleviate the risks of graft failure, contour defects, and donor site morbidity associated with alternative reconstructive options, with good functional and cosmetic outcomes. We advocate their use as a robust reconstructive option in periarticular areas.

Keywords: periarticular, wound closure, skin cancer, fasciocutaneous flaps, keystone flaps

\section{INTRODUCTION}

We report a single-surgeon series of five cases of periarticular keystone flap between 2014 and 2017 (Table 1). Data were collected from operation notes, clinical photography, histopathology, and outpatient clinic records. All patients provided written informed consent for their images and data to be used for research and publication.

The indication for keystone flap was skin cancer in all cases $(n=5)$, consisting of two basal cell carcinomas (BCC) and three melanoma scar excisions. All cases were performed as day case operations. In all cases, melanomas were initially excised with $2 \mathrm{~mm}$ margins to determine Breslow thickness, and the subsequent scar revised with appropriate margins prior to reconstruction. BCC were excised with 4-5 mm margins as per British Association of Dermatology guidelines (1) and demonstrated adequately clear excision margins histologically (Table 1). 
TABLE 1 | Summary of lesion type, size, post-excision defect size, keystone flap subtype, and postoperative complications for included cases.

\begin{tabular}{|c|c|c|c|c|c|c|c|c|c|c|c|}
\hline \multirow[t]{2}{*}{ Case } & \multirow{2}{*}{$\begin{array}{c}\text { Age } \\
\text { (gender) }\end{array}$} & \multirow[t]{2}{*}{ Lesion } & \multirow{2}{*}{$\begin{array}{c}\text { Lesion } \\
\text { size }(\mathrm{mm})\end{array}$} & \multirow[t]{2}{*}{ Area } & \multirow{2}{*}{$\begin{array}{l}\text { Associated } \\
\text { joint(s) }\end{array}$} & \multicolumn{3}{|c|}{ Defect size (mm) } & \multirow[t]{2}{*}{ Histology } & \multirow{2}{*}{$\begin{array}{l}\text { Keystone } \\
\text { flap }\end{array}$} & \multirow{2}{*}{$\begin{array}{l}\text { Follow- } \\
\text { up period } \\
\text { (months) }\end{array}$} \\
\hline & & & & & & Length & Width & Depth & & & \\
\hline 1 & $63(\mathrm{M})$ & Nodular BCC & $18 \times 18$ & Left shoulder & Glenohumeral & 70 & 35 & 5 & Clear with $3 \mathrm{~mm}$ margins & Type 2a & 4 \\
\hline 2 & $79(F)$ & Melanoma scar & $32 \times 22$ & Left popliteal fossa & Knee & 55 & 40 & 12 & No residual melanoma & Type 3 & 18 \\
\hline 3 & $71(\mathrm{~F})$ & Melanoma scar & $45 \times 1$ & Left forearm & Elbow & 75 & 40 & 17 & No residual melanoma & Type 3 & 10 \\
\hline 4 & $58(F)$ & Melanoma scar & $9 \times 8$ & $\begin{array}{l}\text { Left medial } \\
\text { malleolus }\end{array}$ & Ankle & 27 & 12 & 2 & No residual melanoma & Type 1 & 3 \\
\hline 5 & $65(\mathrm{M})$ & Nodular BCC & $27 \times 20$ & Left shoulder & Glenohumeral & 35 & 56 & 11 & Nearest margin 3.9 mm & Type 1 & 3 \\
\hline
\end{tabular}

The defect size post-excision ranged from $75 \mathrm{~mm} \times 40$ $\mathrm{mm} \times 17 \mathrm{~mm}$ to $27 \mathrm{~mm} \times 12 \mathrm{~mm} \times 2 \mathrm{~mm}$ with a mean size of $52 \mathrm{~mm} \times 37 \mathrm{~mm} \times 9 \mathrm{~mm}$ (Table 1). Two keystone flaps were Type 1, two Type 3 flaps (popliteal and antecubital fossa), and a Type $2 \mathrm{a}$ flap adjacent to the glenohumeral joint (Table 1).

All keystone flaps demonstrated a color and cosmetic appearance comparable to adjacent tissue, with minimal scar formation at the periphery (Figure 1). Impaired range of joint movement was neither reported subjectively nor detectable on clinical examination, plus no issues regarding contracture or problematic scarring have been identified in this series to date during the follow-up period. One patient was readmitted 7 days postoperatively with erythema and swelling underlying the keystone flap (Case 5) consistent with a superficial wound infection. Blood tests at the time of readmission demonstrated a normal white cell count and mildly elevated C-reactive protein. Methicillin-sensitive Staphylococcus aureus was identified from wound swabs to be the causative organism. The infection was successfully treated with 7 days of clarithromycin, with no adverse impact on the subsequent healing process. All patients have reported high levels of satisfaction with the appearance of their reconstruction.

\section{BACKGROUND}

The Keystone perforator island flap (Keystone flap), is a local, Type A fasciocutaneous advancement flap, consisting of two V to Y advancement flaps (2). Originally described by Behan et al. (2), its use as a locoregional reconstructive tool offers an attractive alternative to skin grafting and free tissue transfer, reducing complications associated with donor site harvest, blood supply, and cosmetic donor-recipient mismatches (3).

Blood supply to the flap is based on random vascular perforators, with a dual supply from both the subcutaneous vascular plexus and perforating vessels in the fascial and muscular layers (4).

Since their introduction, keystone flaps have been subdivided into four subtypes (Table 1) and used for head and neck (5-8) and lower limb reconstruction (9-11), to resurface irradiated tissue or burn excisions $(12,13)$ and in mobile areas such as the lumbosacral spine $(14,15)$.

Periarticular wound closure is a unique reconstructive challenge due to multi-vector tensional forces (16). Adjacent tissue is continually subjected to stretch, compression and torsion and the reconstructive solution should possess the ability to withstand changes in tensile forces. It is widely known that periarticular skin grafts are subjected to movement and shearing forces, disrupting the formation of early fibrin bonds and leading to increased failure rates $(16-18)$ and contracture $(19,20)$. In our experience, the use of locoregional flaps to reconstruct periarticular defects left from skin cancer excisions are superior to skin grafts, and we illustrate this through the use of the keystone flap in five patients.

\section{DISCUSSION}

To our knowledge, this is the first case series to discuss the use of keystone flaps in periarticular wound closure. Our experience highlights a number of advantages and important learning points to consider during patient selection.

In our study of five patients, the cosmetic outcomes were wellreceived and patient satisfaction was high. This parallels studies using keystone flaps in esthetically sensitive areas such as nasal and facial reconstruction $(5-7,21-23)$. Despite their cosmetic appeal in matching the appearance of adjacent skin (3) a notable scar burden may still be associated with the use of these flaps, especially when under high tension, although this ameliorates with time (Figure 1).

Periarticular wound closure can prove challenging. Moreover, the large antecubital and popliteal fossa defects (Table 2) presented a range of reconstructive challenges beyond the issues of multivector tensile forces, such as exposed neurovascular structures needing robust soft tissue protective cover. The burden of skin cancers in mobile areas, such as the lower leg is high, especially in females (24), and to achieve clear surgical margins often creates large defects. Despite this, there is a sparsity of literature that concerns itself with the most appropriate means of periarticular wound closure. Although keystone flaps have been used previously for generic lower limb reconstruction $(6,25)$ they have not been used widely in the popliteal fossa or periarticular areas to our knowledge. Alternatives to fasciocutaneous flaps such as the keystone include reconstruction with skin grafts, though these do not parallel the robust tissue coverage of local flaps and may exhibit high failure rates (16), particularly in mobile areas where graft adherence may be compromised. In addition, contour defects, pigmentation mismatch (26), and secondary contractures (19) may also restrict cosmetic and functional outcomes, particularly when extrapolated to periarticular defects. Alternative flaps for lower limb wound closure may include reverse flow flaps and local 

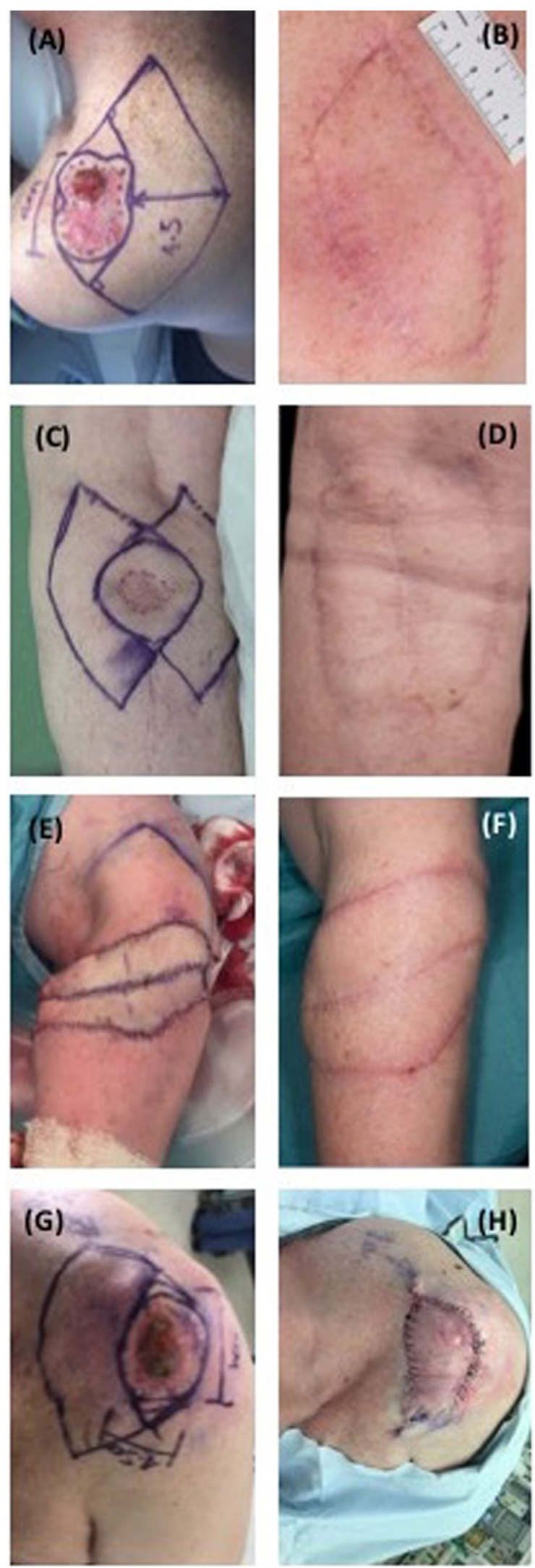

FIGURE 1 | Continued
FIGURE 1 | Continued

Preoperative, intra-operative and postoperative periarticular keystone flaps.

(A) Patient 1, pre-operative; (B) patient 1, 2 months postoperative;

(C) patient 2, pre-operative; (D) patient 2, 2 months postoperative;

(E) patient 3, intra-operative; (F) patient 3, 1 month postoperative;

(G) patient 5, pre-operative; (H) patient 5, intra-operative.

TABLE 2 | Subtypes of Keystone Flap and their surgical applications [Modified from Behan et al 2003 (1); Pelissier et al 2007 (3)].

\begin{tabular}{ll}
\hline Keystone flap subtype & Principles and surgical applications \\
\hline Type I & $\begin{array}{l}\text { Primary defect less than } 2 \mathrm{~cm} \text { width } \\
\text { Lateral deep fascia remains intact }\end{array}$ \\
\hline Type Ila & Defects greater than $2 \mathrm{~cm}$ \\
& Division of deep fascia required to facilitate tissue \\
& mobilization \\
\hline Type IIb & Useful in large defect coverage \\
& Concomitant use of split-skin graft, reduces tension \\
& on flap margins \\
\hline Type III & Large primary defect (5-10 cm) \\
& Two keystone flaps on each border of the defect \\
\hline Type IV & Rotational keystone flap, useful in joint contracture \\
& or open fractures \\
& Flap is raised with up to $50 \%$ sub-facial undermining
\end{tabular}

transposition flaps (27). Reverse flow flaps may compromise the arterial inflow to the foot (27), and although comparable wound coverage may be achieved through transposition, defects of large size or low tissue laxity may require concomitant skin grafting to close the donor site. Similarly, pedicled fasciocutaneous flaps, such as the radial forearm flap (28) have been documented in upper limb periarticular wound closure. However, this often requires a skin graft to close the donor site, and division of the arterial inflow to the hand at the expense of wound closure (29).

It has been reported that keystone flaps around the elbow, knee, and ankle joints should be used cautiously due to reduced skin laxity and a risk of dehiscence (30), and previous studies have reported wound dehiscence following full flexion at the lumbosacral area (25). In our series, we did not immobilize the joints in plaster casts, but advise bulky dressings and enforced rest until wound checks were performed 2 weeks postoperatively. We present several examples of successful keystone flap reconstruction around the joints of the upper and lower limbs with no major complications and throughout the postoperative follow-up, both patient and clinicians were satisfied with the quality of the functional and cosmetic results.

\section{CONCLUDING REMARKS}

Keystone flaps provide an effective means of periarticular wound closure in an area of high mobility and low skin laxity. Locoregional fasciocutaneous wound coverage offered by keystone flaps provide a good cosmetic match, robust soft tissue coverage and avoid contour defects and contracture at a cost of minimal donor site morbidity. On the basis of our experience, we advocate the increased use of the keystone flap to close periarticular defects following skin cancer excision. 


\section{ETHICS STATEMENT}

This is a retrospective, descriptive study in which all patients provided written consent for their images to be used for publication purposes.

\section{AUTHOR CONTRIBUTIONS}

All authors (TJ, ZJ, RS, TD, and IW) have made substantial contributions to the conception or design of the work; or the acquisition, analysis, or interpretation of data for the work. All authors have been involved in drafting the work or revising it critically for important intellectual content and approve the final

\section{REFERENCES}

1. Telfer NR, Colver GB, Morton CA; British Association of Dermatologists. Guidelines for the management of basal cell carcinoma. Br J Dermatol (2008) 159(1):35-48. doi:10.1111/j.1365-2133.2008.08666.x

2. Behan FC. The keystone design perforator island flap in reconstructive surgery. ANZ J Surg (2003) 73(3):112-20. doi:10.1046/j.1445-2197.2003.02638.x

3. Behan FC, Findlay MW, Lo CH. The Keystone Perforator Island Flap Concept. Churchill Livingstone, Elsevier (2012). 227 p. Available from: https:// www.elsevier.com/books/the-keystone-perforator-island-flap-concept/ behan/978-0-7295-3971-5

4. Pelissier P, Santoul M, Pinsolle V, Casoli V, Behan F. The keystone design perforator island flap. Part I: anatomic study. J Plast Reconstr Aesthet Surg (2007) 60(8):883-7. doi:10.1016/j.bjps.2007.01.072

5. Behan FC, Rozen WM, Wilson J, Kapila S, Sizeland A, Findlay MW. The cervico-submental keystone island flap for locoregional head and neck reconstruction. J Plast Reconstr Aesthet Surg (2013) 66(1):23-8. doi:10.1016/j. bjps.2012.08.027

6. Behan FC, Lo CH, Sizeland A, Pham T, Findlay M. Keystone island flap reconstruction of parotid defects. Plast Reconstr Surg (2012) 130(1):36e-41e. doi:10.1097/PRS.0b013e3182547f55

7. Loh IW, Rozen WM, Behan FC, Crock J. Eyelid reconstruction: expanding the applications of the keystone perforator island flap concept. ANZ J Surg (2012) 82(10):763-4. doi:10.1111/j.1445-2197.2012.06222.x

8. Sun Y. Keystone flap for large posterior neck defect. Indian J Surg (2016) 78(4):321-2. doi:10.1007/s12262-015-1406-5

9. Behan FC, Lo CH, Findlay M. Anatomical basis for the keystone island flap in the upper thigh. Plast Reconstr Surg (2010) 125(1):421-3. doi:10.1097/ PRS.0b013e3181c2a66f

10. Hu M, Bordeaux JS. The keystone flap for lower extremity defects. Dermatol Surg (2012) 38(3):490-3. doi:10.1111/j.1524-4725.2011.02236.x

11. Martinez J-C, Cook JL, Otley C. The keystone fasciocutaneous flap in the reconstruction of lower extremity wounds. Dermatol Surg (2012) 38(3):484-9. doi:10.1111/j.1524-4725.2011.02239.x

12. Al-Busaidi AA, Semalesan N, Al-Busaidi SS. Keystone design sliding skin flap for the management of small full thickness burns. Sultan Qaboos Univ Med J (2011) 11(3):412-4.

13. Behan F, Sizeland A, Porcedu S, Somia N, Wilson J. Keystone island flap: an alternative reconstructive option to free flaps in irradiated tissue. ANZ J Surg (2006) 76(5):407-13. doi:10.1111/j.1445-2197.2006.03708.x

14. Gutman MJ, Goldschlager T, Fahardieh RD, Ying D, Xenos C, Danks RA. Keystone design perforator island flap for closure of myelomeningocele. Childs Nerv Syst (2011) 27(9):1459-63. doi:10.1007/s00381-011-1448-3

15. Park H-S, Morrison E, Lo C, Leong J. An application of keystone perforator island flap for closure of lumbosacral myelomeningocele defects. Ann Plast Surg (2016) 77(3):332-6. doi:10.1097/SAP.0000000000000600

16. Stankiewicz M, Coyer F, Webster J, Osborne S. Incidence and predictors of lower limb split-skin graft failure and primary closure dehiscence in day-case surgical patients. Dermatol Surg (2015) 41(7):775-83. doi:10.1097/ DSS.0000000000000391

17. Farhadieh RD, Bulstrode N, Cugno S. Plastic and Reconstructive Surgery: Approaches and Techniques. Chichester: John Wiley \& Sons (2015). version to be published. All authors agree to be accountable for all aspects of the work in ensuring that questions related to the accuracy or integrity of any part of the work are appropriately investigated and resolved.

\section{FUNDING}

ISW would like to acknowledge the support of the Royal College of Surgeons Pump Priming Award 2017-2018. ZJ would like to acknowledge the support of the Medical Research Council. TJ would like to acknowledge the funding of the Royal College of Surgeons Research Fellowship. TJ, TD and ZJ would like to acknowledge the support of the Welsh Clinical Academic Track.

18. Robson MC, Krizek TJ. Predicting skin graft survival. J Trauma (1973) 13(3):213-7. doi:10.1097/00005373-197303000-00005

19. Ragnell A. The secondary contracting tendency of free skin grafts: an experimental investigation on animals. Br J Plast Surg (1952) 5(1):6-24. doi:10.1016/ S0007-1226(52)80003-7

20. Corps BVM. The effect of graft thickness, donor site and graft bed on graft shrinkage in the hooded rat. Br J Plast Surg (1969) 22(2):125-33. doi:10.1016/ S0007-1226(69)80053-6

21. Chaput B, de Bonnecaze G, Lopez R, Benjamin V, Garrido I, Grolleau JL. Modified keystone island flap design for lateral nasal defect: aesthetic subunit consideration. Plast Reconstr Surg Glob Open (2014) 2(9):e213. doi:10.1097/ GOX.0000000000000143

22. Kostopoulos E, Casoli V, Agiannidis C, Konofaos P, Drimouras G, Dounavis A, et al. The keystone perforator island flap in nasal reconstruction: an alternative reconstructive option for soft tissue defects up to $2 \mathrm{~cm}$ J Craniofac Surg (2015) 26(4):1374-7. doi:10.1097/SCS.0000000000001746

23. Kostopoulos E, Agiannidis C, Konofaos P, Kotsakis I, Champsas G, Frangoulis M, et al. Keystone perforator island flap as an alternative reconstructive option for partial thickness alar defects up to 1.5 centimeters. J Craniofac Surg (2016) 27(5):1256-60. doi:10.1097/SCS.0000000000002742

24. Shaw HM, McGovern VJ, Milton GW, Farago GA, McCarthy WH. Malignant melanoma: influence of site of lesion and age of patient in the female superiority in survival. Cancer (1980) 46(12):2731-5. doi:10.1002/10970142(19801215)46:12<2731::AID-CNCR2820461232>3.0.CO;2-2

25. Stone JP, Webb C, McKinnon JG, Dawes JC, McKenzie CD, TempleOberle CF. Avoiding skin grafts: the keystone flap in cutaneous defects. Plast Reconstr Surg (2015) 136(2):404-8. doi:10.1097/PRS.0000000000001449

26. Moncrieff MD, Bowen F, Thompson JF, Saw RPM, Shannon KF, Spillane AJ, et al. Keystone flap reconstruction of primary melanoma excision defects of the leg - the end of the skin graft? Ann Surg Oncol (2008) 15(10):2867-73. doi:10.1245/s10434-008-0018-8

27. Bajantri B, Bharathi RR, Sabapathy SR. Wound coverage considerations for defects of the lower third of the leg. Indian J Plast Surg (2012) 45(2):283-90. doi:10.4103/0970-0358.101299

28. Adkinson JM, Chung KC. Flap reconstruction of the elbow and forearm: a casebased approach. Hand Clin (2014) 30(2):153-63. doi:10.1016/j.hcl.2013.12.005

29. Zenn MR, Jones G. Reconstructive Surgery: Anatomy, Technique, and Clinical Applications. St. Louis, Missouri: Quality Medical Publishing, Inc (2012). 855 p.

30. Rao AL, Janna RK. Keystone flap: versatile flap for reconstruction of limb defects. JClin Diagn Res (2015) 9(3):PC05-7. doi:10.7860/JCDR/2015/ 12595.5631

Conflict of Interest Statement: The authors declare that the research was conducted in the absence of any commercial or financial relationships that could be construed as a potential conflict of interest.

Copyright (c) 2017 Jovic, Jessop, Slade, Dobbs and Whitaker. This is an open-access article distributed under the terms of the Creative Commons Attribution License (CC BY). The use, distribution or reproduction in other forums is permitted, provided the original author(s) or licensor are credited and that the original publication in this journal is cited, in accordance with accepted academic practice. No use, distribution or reproduction is permitted which does not comply with these terms. 